\title{
Insecticide susceptibility of Aedes aegypti populations from Senegal and Cape Verde Archipelago
}

\author{
Ibrahima Dia ${ }^{1 *}$, Cheikh Tidiane Diagne ${ }^{1,2}$, Yamar Ba ${ }^{1}$, Diawo Diallo ${ }^{1}$, Lassana Konate ${ }^{2}$ and Mawlouth Diallo
}

\begin{abstract}
Background: Two concomitant dengue 3 (DEN-3) epidemics occurred in Cape Verde Archipelago and Senegal between September and October 2009. Aedes aegypti was identified as the vector of these epidemics as several DEN-3 virus strains were isolated from this species in both countries. The susceptibility to pyrethroids, organochlorine, organophosphates and carbamate was investigated in two field strains of Aedes aegypti from both countries using WHO diagnostic bioassay kits in order to monitor their the current status of insecticide susceptibility.

Findings: The two tested strains were highly resistant to DDT. The Cape Verde strain was found to be susceptible to all others tested insecticides except for propoxur $0.1 \%$, which needs further investigation. The Dakar strain was susceptible to fenitrothion $1 \%$ and permethrin $0.75 \%$, but displayed reduced susceptibility to deltamethrin, lambda-cyhalothrin and propoxur.

Conclusions: As base-line results, our observations stress a careful management of insecticide use for the control of Ae. aegypti. Indeed, they indicate that DDT is no longer efficient for the control of Ae. aegypti populations in Cape Verde and Dakar and further suggest a thorough follow-up of propoxur susceptibility status in both sites and that of deltamethrin and lambda-cyhalothrin in Ae. aegypti populations in Dakar. Thus, regular monitoring of susceptibility is greatly needed as well as the knowing if this observed resistance/susceptibility is focal or not and for observed resistance, the use of biochemical methods is needed with detailed comparison of resistance levels over a large geographic area.
\end{abstract}

Keywords: Aedes aegypti, Insecticides, Susceptibility, Cape Verde, Senegal

\section{Findings}

\section{Background}

Between September and October 2009, two concomitant epidemics of dengue caused by the serotype dengue 3 (DEN-3) were recorded in Senegal and Cape Verde Archipelago [1,2]. In Senegal 696 suspected cases were recorded with 196 confirmed while in Cape Verde, there were an estimated 210,000 clinical cases of which 174 fitted the WHO definition of DHF/DSS and six were fatal. The majority of cases were on Santiago, Fogo and Maio in the leeward (southern) chain of islands whereas in Senegal the cities of Dakar, Louga and Mbour were of concern. Aedes

\footnotetext{
* Correspondence: dia@pasteur.sn

'Unité d'entomologie médicale, Institut Pasteur de Dakar, 36 Avenue Pasteur, Dakar BP 220, Sénégal

Full list of author information is available at the end of the article
}

aegypti was identified as the vector of these epidemics as several DEN-3 strains were isolated from this species in both countries. In Cape Verde archipelago, since its first report in S. Vicente Island in 1931 [3], it was recently described in Santiago, Fogo and Brava islands $[4,5]$. In Senegal, the presence of Ae aegypti is widespread as it was observed in all bioclimatic zones [6,7]. In response to these epidemics, the Ministry of Health of the two countries launched an emergency vector control campaign, including a major public education effort, and energetic source reduction operation, backed by treatment of breeding sites (mainly in Cape Verde archipelago by temephos use) and indoor and outdoor residual treatment with insecticidal aerosols. Respectively, deltamethrin and propoxur were the insecticides used without proper consideration to control adult Aedes mosquitoes through 
mass spraying while: i) no information was available on the status of Ae. aegypti populations to these insecticides and ii) the development of resistance to organochlorine, organophosphate, carbamate, and pyrethroid insecticides in Ae. Aegypti from subtropical and tropical regions of the world can hinder control efforts [8]. Indeed, as multiple resistances to pyrethroids and organophosphates has been reported in Ae aegypti populations from Asia $[9,10]$, South America and The Caribbean [11-14] and in a lesser extent in Africa [15], control efforts can seriously be compromised by such phenomenon. Therefore, the present work was undertaken to monitor the current status of insecticide susceptibility in Ae. aegypti populations collected from Senegal and Cape Verde for compounds that are in current or planned for future use.

\section{Methods}

Ae. aegypti eggs, 3rd and 4th larvae stages were collected in Dakar $\left(14^{\circ} 45^{\prime} \mathrm{N}, 17^{\circ} 27^{\prime} \mathrm{W}\right)$ and in Santiago island $\left(14^{\circ}\right.$ $\left.54^{\prime} \mathrm{N}, 23^{\circ} 31^{\prime} \mathrm{W}\right)$ in November 2009. Pupae were collected and kept in cages until adult emergence. Adult mosquitoes were maintained with a $10 \%$ sucrose solution.

Bioassays were carried out using WHO tests kits for adult mosquitoes [16]. Insecticide-impregnated papers were provided by The Vector Control Research Unit, School of Biological Sciences (Universiti Sains Malaysia), a WHO Collaborating Centre. The following diagnostic concentrations of insecticides were tested: 4\% DDT, $1 \%$ fenitrothion, $0.1 \%$ propoxur, $0.75 \%$ permethrin, $0.05 \%$ lambda-cyhalothrin, and $0.05 \%$ deltamethrin. For DDT and propoxur, the discriminating concentrations from WHO criteria were used whereas for the others, literature data from previous published studies were used [9,17-19].

Tests were performed on 2-5 day-old unfed females. Batches of 20-25 females were exposed to insecticideimpregnated papers for $30 \mathrm{~min}$ to $4 \%$ DDT and 1 hour to the other tested insecticides. The number of knockdown mosquitoes was recorded every 10 min during exposure. The knockdown times for $50 \%\left(\mathrm{KdT}_{50}\right)$ and $95 \%\left(\mathrm{KdT}_{95}\right)$ of tested mosquitoes were calculated using a log-probit software (StatPlus, version 2009) according to [20]. The mortality rate was recorded after $24 \mathrm{~h}$. Tests with untreated papers were systematically run as control. When control mortality was between 5 and 20\%, mortality rate in tested samples was corrected using Abbott formula [21]. The WHO criteria for determining resistance or susceptibility were applied [8].

\section{Results and discussion}

Resistance to DDT was detected both in Cape Verde and Dakar strains, as mortality rates $24 \mathrm{~h}$ post exposure obtained with this insecticide were respectively 33.3 and 24.4\%. The Cape Verde strain was found to be susceptible to fenitrothion $1 \%$ and the three tested pyrethroids (deltamethrin $0.05 \%$, lambda-cyhalothrin $0.05 \%$ and permethrin $0.75 \%)$. The mortality rate for propoxur was $87.2 \%$, suggesting suspected resistance, and the need of further investigation.

By contrast, the Dakar strain was susceptible only to fenitrothion $1 \%$ and permethrin $0.75 \%$. The mortality rates were respectively $87.2 \%$ for propoxur $1 \%, 94.5 \%$ for deltamethrin $0.05 \%$ and $81.6 \%$ for lambda-cyhalothrin $0.05 \%$ (Table 1). These results also suggest suspected resistance and need to be confirmed.

For the two strains tested, the relationship between knockdown time and the time for exposure was linear. No knock down effect was observed with DDT $4 \%$ for the Dakar strain, for which $\mathrm{KdT}_{50}$ and $\mathrm{KdT}_{95}$ were higher in comparison with the other tested insecticides.

For Permethrin $0.75 \%, \mathrm{KdT}_{50}$ and $\mathrm{KdT}_{95}$ were comparable between the two strains while, for the remaining pyrethroids, $\mathrm{KdT}_{50}$ and $\mathrm{KdT}_{95}$ were higher for Dakar strain in comparison with Cape Verde strain (Table 1).

According to these results, the Cape Verde and Dakar strains tested are resistant to DDT $4 \%$ and exhibit a reduced susceptibility to propoxur $1 \%$. Similar results on DDT resistance were recently obtained in Central Africa in areas where Ae. aegypti and Ae. albopictus are sympatric [15] . This observation is not surprising since DDT and propoxur are extensively used in these areas

Table 1 Percentage mortality in field samples of Aedes aegypti 24 hours after exposure to insecticide-impregnated papers and correspondence with knockdown time (KdT) using WHO test tubes

\begin{tabular}{|c|c|c|c|c|c|c|c|c|c|c|}
\hline \multirow{2}{*}{$\begin{array}{l}\text { Insecticides } \\
\text { (diagnostic dose) }\end{array}$} & \multicolumn{5}{|c|}{ Cape Verde strain } & \multicolumn{5}{|c|}{ Dakar strain } \\
\hline & $\mathbf{N}$ & $\begin{array}{c}\text { Mortality } \\
(\%)\end{array}$ & $\begin{array}{l}\mathrm{KDT}_{50} \\
\text { (min) }\end{array}$ & $\begin{array}{l}\mathrm{KDT}_{95} \\
\text { (min) }\end{array}$ & $\begin{array}{c}\text { Resistance } \\
\text { status }\end{array}$ & $\mathbf{N}$ & $\begin{array}{c}\text { Mortality } \\
(\%)\end{array}$ & $\begin{array}{l}\mathrm{KDT}_{50} \\
\text { (min) }\end{array}$ & $\begin{array}{l}\mathrm{KDT}_{95} \\
\text { (min) }\end{array}$ & $\begin{array}{c}\text { Resistance } \\
\text { status }\end{array}$ \\
\hline DDT (4\%) & 231 & 33.3 & 78.8 & 288.7 & $\mathrm{R}$ & 214 & 24.4 & - & - & $\mathrm{R}$ \\
\hline Propoxur (0.1\%) & 233 & 87.2 & 23.5 & 38.8 & $\mathrm{RPC}$ & 228 & 87.2 & 23.9 & 73.9 & $\mathrm{RPC}$ \\
\hline Fenitrothion (1\%) & 123 & 100 & - & - & $\mathrm{S}$ & 125 & 99.1 & - & - & $\mathrm{S}$ \\
\hline Deltamethrin (0.05\%) & 228 & 100 & 9.6 & 27 & $\mathrm{~S}$ & 189 & 94.5 & 15.7 & 30.3 & $\mathrm{RPC}$ \\
\hline $\begin{array}{l}\text { Lambda-Cyhalothrin } \\
(0.05 \%)\end{array}$ & 125 & 100 & 14.5 & 26.9 & S & 125 & 81.6 & 18.6 & 34.2 & $\mathrm{RPC}$ \\
\hline Permethrin $(0.75 \%)$ & 123 & 100 & 7.2 & 21.8 & $\mathrm{~S}$ & 125 & 100 & 11.3 & 20.5 & $S$ \\
\hline
\end{tabular}

$\mathrm{N}=$ number of specimens tested; $\mathrm{S}=$ susceptible: $\mathrm{R}=$ resistant; $\mathrm{RPC}=$ resistance possible to be confirmed. 
for mosquito control as well as for market gardening crop protection causing contamination of natural breeding sites [22]. For DDT, these authors have shown huge resistance of the main malaria vector (Anopheles arabiensis) in Dakar and Pikine, one of the main surrounding neighbourhoods. Indeed, the contamination of larval breeding sites by insecticide used in agriculture is often associated to the selection for DDT and others insecticides resistance in diseases vectors [23,24]. Residual spraying using DDT was the principal method for malaria eradication in Cape Verde archipelago [25] and Ae. aegypti control in Dakar [26] between the 1940s and 1960s. As a result, the long term and extensive use of DDT would have led to a strong selective pressure on exposed mosquito populations and could explain the high resistance to DDT observed in our two strains. Indeed, DDT resistance has been widely observed in Ae. aegypti worldwide. $K d r$ mutation of the voltage-gated sodium channel as well as detoxifying enzymes such as glutathione S-transferases have been found to play a key role in DDT metabolism and resistance [27-29]. Therefore, as cross-resistance between DDT and pyrethroids has been extensively demonstrated to be associated with $k d r$ mutation in their common target site, this may have serious consequences for insecticide-based Ae. aegypti control programmes. For the other tested insecticides, the susceptibility of Cape Verde strain compared to the Dakar strain could be the result of non-use or rare use of these insecticides. In fact, apart from deltamethrin that is extensively used in IRS for malaria control, no other official insecticide is used for vector control.

For the Dakar strain, there is a decreased susceptibility to deltamethrin $0.05 \%$ and lambda-cyhalothrin $0.05 \%$. However, it is interesting to note that the $\mathrm{KDT}_{50}$ and $\mathrm{KDT}_{95}$ are comparable with the values obtained with the Cape Verde strain that was fully susceptible to these insecticides.

\section{Conclusions}

This study reports for the first time the susceptibility of Ae. aegypti populations to commonly used insecticides. Our results indicate that DDT is no longer efficient for the control of Ae. aegypti populations in Cape Verde and Dakar. They further suggest a thorough follow-up of propoxur susceptibility status in both sites and that of deltamethrin and lambda-cyhalothrin in Ae. aegypti populations in Dakar. In addition, regular monitoring of susceptibility is greatly needed. It is also important to know if this observed resistance/susceptibility is focal or not and for observed resistance, the use of biochemical methods is needed with detailed comparison of resistance levels over a large geographic area.

\section{Competing interests}

The authors declare that they have no competing interests.

\section{Authors' contributions}

ID and MD designed and supervised the study. ID, CTD and DD performed the susceptibility tests. ID, CTD, MD analyzed the data. ID and MD drafted and revised the manuscript. All authors revised and approved the final version of the manuscript.

\section{Acknowledgments}

The authors gratefully acknowledge the medical authorities of Cape Verde and Senegal and WHO office in Cape Verde, Amadou THIAW for its technical assistance in mosquito colonies maintenance.

\section{Author details}

${ }^{1}$ Unité d'entomologie médicale, Institut Pasteur de Dakar, 36 Avenue Pasteur, Dakar BP 220, Sénégal. 'Laboratoire d'écologie vectorielle et parasitaire, Département de Biologie Animale, Université Cheikh Anta Diop, Dakar BP 5005, Senegal.

Received: 10 September 2012 Accepted: 20 October 2012

Published: 22 October 2012

\section{References}

1. Franco L, Di Caro A, Carletti F, Vapalahti O, Renaudat C, Zeller H, Tenorio A: Recent expansion of dengue virus serotype 3 in West Africa. Euro Surveill 2010, 15(7). pii: 19490.

2. World Health Organization: Dengue fever, Cape Verde. Wkly Epidemiol Rec 2009, 84(45):469.

3. Ribeiro H, Ramos HC, Capela RA, Pires CA: Os mosquitos de Cabo Verde (Diptera: Culicidae) - sistemática, distribuição, bioecologia e importância médica. Lisboa: Junta de Investigações Científicas do Ultramar; 1980:141.

4. Alves J, Gomes B, Rodrigues R, Silva J, Arez AP, Pinto J, Sousa CA: Mosquito fauna on the Cape Verde Islands (West Africa): an update on species distribution and a new finding. J Vector Ecol 2010, 35(2):307-312.

5. Duarte EH, Correia EE, Varela CE, Varela A: Reproduction of mosquitoes (Diptera: Culicidae) in Santa Cruz, Santiago island, Cape Verde Islands. Zool Caboverdiana 2012, 3(1):29-36.

6. Diallo M, Ba Y, Faye O, Soumare ML, Dia I, Sall AA: Vector competence of Aedes aegypti populations from Senegal for sylvatic and epidemic dengue 2 virus isolated in West Africa. Trans R Soc Trop Med Hyg 2008, 102(5):493-498.

7. Sylla M, Bosio C, Urdaneta-Marquez L, Ndiaye M, Black WC 4th: Gene flow, subspecies composition, and dengue virus-2 susceptibility among Aedes aegypti collections in Senegal. PLOS Negl Trop Dis 2009, 3(4):e408.

8. World Health Organization: Instructions for determining the susceptibility or resistance of adult mosquito to organochlorine organophosphate and carbonate insecticides-diagnostic test (WHONBC/1981). Geneva: WHO; 1981.

9. Jirakanjanakit N, Rongnoparut P, Saengtharatip S, Chareonviriyaphap T, Duchon S, Bellec C, Yoksan S: Insecticide susceptible/resistance status in Aedes (Stegomyia) aegypti and Aedes (Stegomyia) albopictus (Diptera: Culicidae) in Thailand during 2003-2005. J Econom Entomol 2007, 100(2):545-550

10. Jirakanjanakit N, Saengtharatip S, Rongnoparut P, Duchon S, Bellec C, Yoksan S: Trend of Temephos resistance in Aedes (Stegomyia) mosquitoes in Thailand during 2003-2005. Environ Entomol 2007, 36(3):506-511.

11. Lima EP, Paiva MH, de Araújo AP, da Silva EV, da Silva UM, de Oliveira LN, Santana AE, Barbosa CN, de Paiva Neto CC, Goulart MO, Wilding CS, Ayres CF, de Melo Santos MA: Insecticide resistance in Aedes aegypti populations from Ceará, Brazil. Parasit Vectors 2011, 4:5.

12. Rawlins SC, Martinez R, Wiltshire S, Legall G: A comparison of surveillance systems for the dengue vector Aedes aegypti in Port of Spain, Trinidad. J Am Mosa Control Assoc 1998, 14(2):131-136.

13. Rodriguez MM, Bisset JA, De Armas Y, Ramos F: Pyrethroid insecticide resistant strain of Aedes aegypti from Cuba induced by deltamethrin selection. J Am Mosa Control Assoc 2005, 21(4):437-445.

14. Marcombe S, Carron A, Darriet F, Etienne M, Agnew P, Tolosa M, Yp-Tcha MM, Lagneau C, Yébakima A, Corbel V: Reduced Efficacy of Pyrethroid Space Sprays for Dengue Control in an Area of Martinique with Pyrethroid Resistance. Am J Trop Med Hyg 2009, 80(5):745-751.

15. Kamgang B, Marcombe S, Chandre F, Nchoutpouen E, Nwane P, Etang J, Corbel V, Paupy C: Insecticide susceptibility of Aedes aegypti and Aedes albopictus in Central Africa. Parasit Vectors 2011, 4:79. 
16. World Health Organization: Tests procedures for insecticide resistance monitoring in malaria vectors, bioefficacy and persistence of insecticides on treated surfaces, Report of the WHO informal Consultation (WHO/MAL/98). Geneva: WHO; 1998.

17. Somboon P, Prapanthadara L, Suwonkerd W: Insecticide susceptibility tests of Anopheles minimus, Aedes aegypti, Ae. Albopictus and Culex quinquefasciatus in Northern Thailand. Southeast Asian J Trop Med Public Health 2003, 34:87-93.

18. Sathantriphop S, Paeporn P, Supaphathom K: Detection of insecticides resistance status in Culex quinquefasciatus and Aedes aegypti to four major groups of insecticides. Trop Biomed 2006, 23:97-101.

19. Surendran SN, Kajatheepan A, Sanjeefkumar KF, Jude PJ: Seasonality and insecticide susceptibility of dengue vectors: an ovitrap based survey in a residential area of northern Sri Lanka. Southeast Asian J Trop Med Public Health 2007, 38:276-282.

20. Finney DJ: Probit Analysis. Cambridge: Cambridge University Press; 1971.

21. Abbott WS: A method of computing the effectiveness of an insecticide. J Econ Entomol 1925, 18:265-267.

22. Faye O, Gaye O, Diallo S: Evaluation de la sensibilité d'Anopheles gambiae s.l. au Fenitrothion, au Malathion et au DDT au Sénégal. Dakar Med 1991, 36:170-177.

23. Yadouleton A, Martin T, Padonou G, Chandre F, Asidi A, Djogbenou L, Dabiré R, Aikkpon R, Boko M, Glitho I, Akogbeto M: Cotton pest management practices and the selection of pyrethroid resistance in Anopheles gambiae population in northern Benin. Parasit Vectors. 2011 4:60.

24. Koffi AA, Alou LP, Adja MA, Koné M, Chandre F, N'guessan R: Update on resistance status of Anopheles gambiae s.s. to conventional insecticides at a previous WHOPES field site, "Yaokoffikro", 6 years after the political crisis in Côte d'Ivoire. Parasit Vectors 2012, 5:68.

25. Kouznetsov RL: Malaria control by application of indoor spraying of residual insecticides in tropical Africa and its impact on community health. Trop Doct 1977, 7(2):81-91.

26. Breteau H: La fièvre jaune en Afrique occidentale française. Un aspect de la médecine préventive massive. Bull World Health Org 1954, 11:453-481.

27. Marcombe S, Poupardin R, Darriet F, Reynaud S, Bonnet J, Strode C, Brengues C, Yébakima A, Ranson H, Corbel V, David JP: Exploring the molecular basis of insecticide resistance in the dengue vector Aedes aegypti: a case study in Martinique Island (French West Indies). BMC Genomics 2009, 10:494.

28. Brengues C, Hawkes NJ, Chandre F, McCarroll L, Duchon S, Guillet P, Manguin S, Morgan JC, Hemingway J: Pyrethroids and DDT crossresistance in Aedes aegypti is correlated with novel mutations in the voltage-gated sodium channel gene. Med Vet Entomol 2003, 17(1):87-94.

29. Lumjuan N, McCarroll L, Prapanthadara LA, Hemingway J, Ranson H: Elevated activity of an Epsilon class glutathione transferase confers DDT resistance in the dengue vector, Aedes aegypti. Insect Biochem Mol Biol 2005, 35:861-871.

doi:10.1186/1756-3305-5-238

Cite this article as: Dia et al: Insecticide susceptibility of Aedes aegypti populations from Senegal and Cape Verde Archipelago. Parasites \& Vectors 2012 5:238.

\section{Submit your next manuscript to BioMed Central and take full advantage of:}

- Convenient online submission

- Thorough peer review

- No space constraints or color figure charges

- Immediate publication on acceptance

- Inclusion in PubMed, CAS, Scopus and Google Scholar

- Research which is freely available for redistribution 